\title{
Assessment of some Biomarkers in Liver, Kidney and Stomach Following Pineapple Juice Administration
}

\author{
Oyesola T.O. ${ }^{1}$, Oyesola O.A. ${ }^{2}$, Odukoya S.O.A. ${ }^{* 3}$ and Adelodun S.T. ${ }^{3}$ \\ ${ }^{1}$ Department of Anatomy, Ben Carson (Snr.) School of Medicine, Babcock University, \\ Ilisan Remo, Nigeria. \\ ${ }^{2}$ Department of Physiology, Ogun State University, Ikene, Nigeria \\ ${ }^{3}$ Department of Anatomy and Cell Biology, Obafemi Awolowo University, Ile-Ife, Nigeria. \\ tolusoji2001@yahoo.com,olusoji.oyesola@yahoo.com, adeloduntaiye@gmail.com \\ goshevnigeria@yahoo.com*
}

Keywords: Physiochemical, Pineapple juice, Stomach, Kidney, Liver, Hematology, Cholesterol.

\begin{abstract}
This study looked into the physiochemical assessment of kidney, liver and stomach following pineapple juice (PJ) administration in normal Wistar rats. Thirty-two young male Wistar rats weighing between 180 - $200 \mathrm{~g}$ were used for this study. The juice was administered through oral cannula for 30 days. The animals were grouped into four (A-D). Group A received $3 \mathrm{ml}$ of distilled water (Control), Group B received $3 \mathrm{ml} / \mathrm{kg}$ PJ, Group C received $6 \mathrm{ml} / \mathrm{kg}$ PJ administered at $3 \mathrm{ml}$ twice daily and Group D received $9 \mathrm{ml} / \mathrm{kg}$ PJ at $3 \mathrm{ml}$ three times daily for one month. Blood samples were collected a day post-administration through cardiac puncture for hematological and biochemical studies. Mucosal tissues were scraped from the stomach and homogenized to check for total protein and some other gastric enzymes. The study showed a significant decrease $(\mathrm{P}<0.05)$ in cholesterol and triglycerides (113.4 $\pm 1.60-104.4 \pm 1.66$ and 104.4 $\pm 1.66-74.0 \pm 2.95)$ while low density and high density lipoproteins showed no significant difference. Electrolyte concentrations of sodium, potassium, chloride, bicarbonate, urea and creatinine showed significant decreases. Liver enzyme parameters were significantly increased $(\mathrm{P}>0.05)$ for ALP $(40.0 \pm 4.05-79.4 \pm 6.61 \mathrm{IU} / \mathrm{L})$, AST $(115.2 \pm 1.46-178.4 \pm 2.00 \mathrm{IU} / \mathrm{L})$, ALT $(86.0 \pm 2.68-72.2 \pm 3.90 \mathrm{IU} / \mathrm{L})$ and ALB $(3.16 \pm 0.09-$ $3.84 \pm 0.02 \mathrm{IU} / \mathrm{L})$. Results of Total Protein showed a significant increase while bilirubin is insignificantly different compared with the control. Results for SOD, TBAR, CATAL and MDA showed no significant differences. The study revealed that the hematological parameters assayed: $\mathrm{Hb}(11.85 \pm 2.0-14.12 \pm 1.5 \mathrm{~g} / 100 \mathrm{ml}), \mathrm{RBC}$ count $\left(6.27 \pm 0.1-9.92 \pm 1.5 \times 10^{6} / \mathrm{mm} 3\right)$ and Total WBC counts $(2.35 \pm 0.6-4.47 \pm 0.5 \times 103 / \mathrm{mm} 3)$ were significantly higher $(\mathrm{P}<0.05)$. We concluded that the oral administration of PJ to Wistar rats for one month is beneficial by reducing cholesterol level and some toxic gastric enzymes. It also increased hematopoietic outputs, and served as an immune booster judging from the Total WBC count results while its effect on liver function is minimal based on this present study.
\end{abstract}

\section{INTRODUCTION}

Pineapple (Ananas comosus), is a tropical plant with edible multiple fruit consisting of coalesced berries, named for resemblance to the pine cone, it is the most economically important plant in the Bromeliaceae family [1].

Hundred grams (100 g) of fresh ripe pineapple was reported by [2] to contain; Water (86.5 g), Energy (49 kcal), Fat (0.43 g), Protein (0.39 g), Carbohydrate (12.39 g), Fiber (1.2 g), Potassium $(1.3 \mathrm{mg})$, Iron $(0.37 \mathrm{mg})$, Selenium $(0.6 \mathrm{mcg})$, Vitamin C $(15.4 \mathrm{mg})$, Vitamin A (23 UI), Vitamin B $(0.092 \mathrm{mg})$, Vitamin $\mathrm{B}_{2},(0.036 \mathrm{mg})$, Vitamin E $(0.10 \mathrm{mg})$, Niacin $(0.42 \mathrm{mg})$, Folic Acid $(11 \mathrm{mcg})$ and Zinc $(0.08 \mathrm{mg})$ [3].

Pineapple juice was reported to have huge nutritive and medicinal value or properties that can be linked to its various compositions. It has the ability to digest food by breaking down protein because it contains proteolytic enzyme called Bromelain [4,5]. 
Some of the reported properties include anti-inflammatory, anti-parasitic and anti-helmintic agents. The root of pineapple was used as decoction to treat diarrhea. It helps to fight infection by dissolving layers of slough and bacterial rich surfaces. It was reported that it clears bronchial passages in those suffering with pneumonia and bronchitis. Similarly, it reduced symptoms of arthritis, pains after surgery and sports injuries [6-9]. Pineapple juice in diet, was reported to naturally reduce the amount of cholesterol in bloodstream $[4,5]$.

Vitamin B1 or thiamine, found in pineapples was reported to allow cells of the body to convert carbohydrates into energy, promotes the function of the heart, muscle and nervous system and also crucial for red blood cell formation [2].

Trace elements found in pineapple including manganese was reported to promote formation of bone, and creation and activation $\backslash$ of certain enzymes. Copper, another trace mineral assists in the absorption of iron and regulation of blood pressure and heart rate. Fibers in pineapple was reported to lower blood cholesterol, which reduces the risks of heart disease, diabetes, constipation, metabolic syndrome, high blood pressure, excess abdominal weight and high triglyceride levels [2]. In another study reported by Rajendra et al., (2012), pineapple's medicinal properties were attributed to Bromelain; which is a crude extract from pineapple [10]. It was chemically known since 1875. It contains compounds that are related to proteinases and has fibrinolytic, antiedematous, anti-thrombotic and anti-inflammatory activities, both in-vivo and in-vitro [11-12].

The concentration of Bromelain is high in the pineapple stem unlike the fruit which is used as food [13]. Therapeutic benefits associated to Bromelain include its curative activities in reversible platelet aggregation inhibition, sinusitis and surgical traumas, thrombophlebitis, pyelonephritis, angina pectoris, bronchitis, and enhanced absorption of drugs, particularly of antibiotics [14-15].

Bromelain was recommended as a supportive therapeutic approach during the treatment of chronic inflammatory, malignant and auto-immune disease [16]. Animal in-vitro experiment showed its ability to modulate surface adhesion of $\mathrm{T}$ cells, macrophages and natural killer cells among others [17-23].

It was reported that fruits and vegetables consumption promotes good health; therefore, wide publicity and recommendation were given for their consumption because they have been implicated for their health promoting properties in most developed countries [24]. The performance and efficiency of any body system is a function of the activities going on within the vital organs of the body system. The performance of these vital organs had been evaluated by some biological markers.

The levels of the following biomarkers were reported in the evaluation of liver performance; Bilirubin, Alanine aminotransferase, Aspartate aminotransferase, and Alkaline phosphatase [25-27]. Osuala et al., 2014 reported the evaluation of kidney performance by the level of Urea, Uric acid and creatine among others [28].

In view of the above considerations this study was conducted to evaluate the possible effects of pineapple juice administration on the Liver, kidney and the stomach of male Wistar rats with references to the lipid profile, organ weight and body mass index.

\section{MATERIALS AND METHODS}

Preparation of Pineapple Juice (PJ): The pineapple fruits were obtained from the new Benin market in Edo state of Nigeria. The juice was extracted with a juice extractor after peeling. The coring and macerating of the pineapple fruit was done by the juice extractor. The juice was collected, stored in a clean bottle and kept inside a refrigerator (deep freezer) for preservation before administration to the rats following the method of [29].

Animal Grouping and administration of PJ: Thirty-two young male Wistar rats weighing between $180-200 \mathrm{~g}$ were used for this study. The animals were obtained from a reputable animal house in Benin, Edo state Nigeria. They were transferred to the animal house of Igbinedion University Okada. They were kept in separate cages of eight animals per cage constituting a group. They were allowed four weeks to acclimatize, prior to the commencement of the experiment. The 
animals in each group were labeled from A to D. Group A was the control group for this study, given free access to water under standard condition of temperature and humidity. Group A animals received $3 \mathrm{ml} / \mathrm{kg}$ of distilled water, Group B received $3 \mathrm{ml} / \mathrm{kg}$ of pineapple juice, Group C received $6 \mathrm{ml} / \mathrm{kg}$ of pineapple juice administered $3 \mathrm{ml}$ twice daily and Group D received $9 \mathrm{ml} / \mathrm{kg}$ of pineapple juice at $3 \mathrm{ml}$ thrice daily using oral cannula for 30 days.

Collection of Blood Sample: Blood samples were collected through cardiac puncture under anaesthesia (Sodium Pentobarbital) at $60 \mathrm{mg} / \mathrm{kg}$ body weight intra-peritoneally. The blood samples were stored in heparinized tubes, centrifuged and the serum kept in a plain bottle stored in freezer for further processing.

Stomach Tissue Collection and Preparation: The mucosal tissue from each animal was scraped from the stomach with a blunt knife, the tissue was weighed and transferred to the ice-cooled test tubes for homogenization. The homogenate was then centrifuged at $12,000 \mathrm{rpm}$ at $4^{\circ} \mathrm{C}$ for $10 \mathrm{~min}$. Supernatant aliquot was decanted and stored in a freezer for determination of total protein (TP), Catalase (CAT), Superoxide Dismutase (SOD) and Malondialdehyde (MDA).

Total Protein Content Determination: The total protein content of the blood and the stomach tissue were estimated by the method of Lowry et al., (1951) using bovine serum albumin as a standard [30].

Catalase Activity Determination: Catalase activty was determined in the blood and the stomach tissue according to the procedure of Goth (1991) by following the absorbance of hydrogen peroxide at $230 \mathrm{~nm}$ at $\mathrm{pH} 7.0$ [31].

Superoxide Dismutase Activity Determination: The activity of SOD was determined by measuring the inhibition of autooxidation of epinephrine at $\mathrm{pH} 10.2$ at $30^{\circ} \mathrm{C}$ by the method of Misra and Fridovich (1972) [32] One unit of SOD activity represents the amount of SOD necessary to cause $50 \%$ inhibition of adrenaline autooxidation.

Malondialdehyde Level Determination: Lipid peroxidation of the blood and the tissue were determined spectrophotochemiocally at $533 \mathrm{~nm}$ and MDA concentration was quantified by using the molar extinction coefficient, $1.56 \times 105 \mathrm{~mol}^{-1} \mathrm{Ecm}^{-1}[33]$.

\section{Lipid Profile Determination}

Determination of Total Cholesterol: The total cholesterol concentration of the sample was estimated according to the enzymatic method (PAPS Protocol) of Agappe Diagnostics Kit, India.

Organ weight Determination: The weight of Liver, Kidney and Stomach were determined per gramm body weight.

Urea Level Determination: Urea was assayed according to the method described in Randox urea kits. $2.50 \mathrm{ml}$ of reagents 1,2 and 3 were added to 10 micro litter of plasma sample and were mixed immediately and incubated at $37^{\circ} \mathrm{C}$ for 10 minutes. The absorbance of plasma sample and standard were measured against the blank at $546 \mathrm{~nm}$.

Creatinine Level Determination: Creatinine was assayed according to the method described in Randox kits. $2.0 \mathrm{ml}$ of working reagent was added to $0.2 \mathrm{ml}$ of plasma. This was measured against the blank containing standard solution. It was mix and after 30 seconds, the absorbance of A1 of the standard and plasma were read at $492 \mathrm{~nm}$. Exactly 2 minutes later, absorbance of A2 of standard and plasma were read at $492 \mathrm{~nm}$.

Electrolyte Level Determination: Sodium, Potassium, Bicarbonate and Chloride concentration Sera sample from the centrifuge blood was used for the analysis according to the method descibed by Abubakar and Sule (2010) [34]. Serum sodium and potassium concentrations were determined using flame emission photometry method of Magoshes and Vallee (1956) [35], which was based on the dissolution of solution containing these elements by a flame, leaving solid (salts), which dissociates to neutral ground state atoms. These atoms become excited in the flame, thus moving to a higher energy state and the excited atoms fall back to the ground state, light of characteristic 
wavelength is emitted (590 $\mathrm{nm}$ for sodium and $770 \mathrm{~nm}$ for potassium). This light then passes through a suitable filter onto a photosensitive element and the amount of current produced is measured and this is proportioned to the amount of sodium or potassium present in the original sample. Serum chloride concentration was determined using the titration method of Schales and Schales (1941) [36]. The method is based on the precipitation of chloride ions in serum using mercuric nitrate. When chloride ion is titrated with standard solution of mercuric ion undissociated but soluble mercuric chloride, $\mathrm{HgCl}_{2}$, is formed. The excess mercuric nitrate reacts with diphenylcarbazone to produce a violet colour. Titration method of Van Slyke and Neil (1924) [37] was employed in determining the concentration of bicarbonate ion in sera samples. The method is based on the release of carbon dioxide from bicarbonate ion in serum with dilute hydrochloric acid. The excess acid was then titrated with sodium hydroxide using phenol red as indicator.

Liver Enzymes Determination: The activities of liver enzymes such as AST, ALT and ALP were determined using diagnostic kits. Albumin was determined by the bromocresol green method [38], bilirubin was estimated by the method described by Jendrassik and Grof (1938) [39]. Alanine and Aspartate aminotransferases were determined based on the colorimetric measurement of hydrazone formed with 2, 4 dinitrophenyl hydrazine [40], alkaline phosphatase by the phenolphthalein monophosphate method (Babson, 1965) [41].

\section{Determination of Serum Alanine Aminotransferase (ALT) activity}

This was carried out according to the method of Reitman and Frankel (1957) [40]. Diluted sample $(0.01 \mathrm{~mL})$ was mixed with phosphate buffer $(100 \mathrm{mM}, \mathrm{pH} 7.4), \mathrm{L}$-alanine $(200 \mathrm{mM})$ and the mixture was incubated for exactly 30 minutes at $37{ }^{\circ} \mathrm{C} .0 .5 \mathrm{ml}$ of 2,4 dinitrophenylhydrazine $(2 \mathrm{mM})$ was added to the reaction mixture and allowed to stand for exactly 20 minutes at $25{ }^{\circ} \mathrm{C}$. Then $5 \mathrm{ml}$ of $\mathrm{NaOH}(0.4 \mathrm{M})$ was added and the absorbance was read against reagent blank after 5 minutes at $546 \mathrm{~nm}$. Reagent blank was prepared as described above by replacing sample with $0.1 \mathrm{ml}$ of distilled water.

\section{Determination of Serum Aspartate Aminotransferase (AST) activity}

This was carried out according to the method of Reitman and Frankel (1957) [40]. Briefly, 0.1ml of diluted sample was mixed with phosphate buffer (100 mM, pH 7.4), L-asparatate (100 mM), and $\alpha$ Oxoglutarate $(2 \mathrm{mM})$ and the mixture was incubated for exactly 30 minutes at $37{ }^{\circ} \mathrm{C} .0 .5 \mathrm{ml}$ of 2,4 dinitrophenylhydrazine $(2 \mathrm{mM})$ was then added to the reaction mixture and allowed to stand for exactly 20 minutes at $25{ }^{\circ} \mathrm{C}$. Then $0.5 \mathrm{ml}$ of $\mathrm{NaOH}(0.4 \mathrm{M})$ was added and the absorbance was read against reagent blank after 5 minutes at $546 \mathrm{~nm}$. Reagent blank was prepared as described above replacing sample with 0.1 of distilled water.

\section{Determination of Alkaline Phosphatase (ALP)}

$2.2 \mathrm{ml}$ of $0.1 \mathrm{M}$ carbonate buffer $(\mathrm{pH} \mathrm{10.1),} 0.1 \mathrm{ml}$ of $0.1 \mathrm{M} \mathrm{MgSO} 4.7 \mathrm{H} 20$, and $0.2 \mathrm{ml}$ of the sample were mixed together and incubated at $37{ }^{\circ} \mathrm{C}$ for 10 minutes. Thereafter, $0.5 \mathrm{ml}$ of $19 \mathrm{mM}$ of paranitrophenyl phosphate was added and again incubated at $37{ }^{\circ} \mathrm{C}$ for 10 minutes. $2.0 \mathrm{ml} \mathrm{NaOH}$ was added and mixed, and read against blank at $400 \mathrm{~nm}$.

Statistical Analysis: Data are presented as Mean \pm SEM. Data collected were analyzed using Oneway ANOVA and Student Newman- Keuls post- hoc test for multiple comparisons. 


\section{RESULTS}

Table 1: Effects of PJ on Mean Organ Weight

\begin{tabular}{|l|l|l|l|}
\hline Experimental Groups & Liver weight $(\%$ b.w) & Kidney weight (\% b.w) & Stomach weight (\% b.w) \\
\hline Control & $3.76 \pm 0.12$ & $0.89 \pm 0.04$ & $1.24 \pm 0.02$ \\
\hline $3 \mathrm{ml} / \mathrm{kg} P J$ & $3.22 \pm 0.25^{*}$ & $0.72 \pm 0.03^{*}$ & $0.96 \pm 0.04^{*}$ \\
\hline $6 \mathrm{ml} / \mathrm{kg} P J$ & $2.95 \pm 0.16^{*}$ & $0.66 \pm 0.02^{*}$ & $0.79 \pm 0.03^{*}$ \\
\hline $9 \mathrm{ml} / \mathrm{kg} P J$ & $2.85 \pm 0.10^{*}$ & $0.72 \pm 0.04^{*}$ & $0.89 \pm 0.05^{*}$ \\
\hline
\end{tabular}

Results are presented as Mean \pm SEM. Data are compared down the table

* Significantly different from Control at $\mathrm{p}<0.05$, b.w $=$ body weight

Table 2: Effects of Pineapple Juice on Lipid Parameters in Wistar Rats

\begin{tabular}{|l|l|l|l|l|}
\hline $\begin{array}{l}\text { Experimental } \\
\text { Groups }\end{array}$ & $\begin{array}{l}\text { Cholesterol } \\
(\mathrm{mg} / \mathrm{dl}-1)\end{array}$ & $\begin{array}{l}\text { Triglyceride } \\
(\mathrm{mg} / \mathrm{dl}-\mathrm{l})\end{array}$ & $\begin{array}{l}\text { Low Density } \\
\text { Lipo-protein } \\
(\mathrm{mg} / \mathrm{dl}-1)\end{array}$ & $\begin{array}{l}\text { High Density } \\
\text { Lipo-protein } \\
(\mathrm{mg} / \mathrm{dl}-1)\end{array}$ \\
\hline Control & $113.4 \pm 1.60$ & $83.4 \pm 0.60$ & $43.4 \pm 0.98$ & $38.6 \pm 2.75$ \\
\hline $3 \mathrm{ml} / \mathrm{kg} P J$ & $107.2 \pm 1.28^{\#}$ & $76.0 \pm 2.05^{*}$ & $48.4 \pm 3.43$ & $36.4 \pm 3.53$ \\
\hline $6 \mathrm{ml} / \mathrm{kg} P J$ & $110.0 \pm 1.52$ & $71.8 \pm 1.71^{\#}$ & $49.4 \pm 0.98$ & $46.8 \pm 2.03^{\#}$ \\
\hline $9 \mathrm{ml} / \mathrm{kg} P J$ & $104.4 \pm 1.66^{\#}$ & $74.0 \pm 2.95^{\#}$ & $54.2 \pm 4.44^{\#}$ & $30.0 \pm 3.42^{\#}$ \\
\hline
\end{tabular}

Table 3: Effects of Pineapple Juice on some Electrolytes Level in the Kidney of Wistar Rats

\begin{tabular}{|l|l|l|l|l|l|l|}
\hline $\begin{array}{c}\text { Experimental } \\
\text { Groups }\end{array}$ & $\begin{array}{l}\text { Urea } \\
(\mathrm{mg} / \mathrm{dl})\end{array}$ & $\begin{array}{l}\text { Creatinine } \\
(\mathrm{mg} / \mathrm{dl})\end{array}$ & $\begin{array}{l}\text { Sodium } \\
(\mathrm{mEq} / \mathrm{L})\end{array}$ & $\begin{array}{l}\text { Potassium } \\
(\mathrm{mEq} / \mathrm{L})\end{array}$ & $\begin{array}{l}\text { Bicarbonate } \\
(\mathrm{mmol} / \mathrm{L})\end{array}$ & $\begin{array}{l}\text { Chloride } \\
(\mathrm{mmol} / \mathrm{L})\end{array}$ \\
\hline Control & $41.08 \pm 2.24$ & $0.64 \pm 0.07$ & $130.4 \pm 0.40$ & $3.82 \pm 0.05$ & $30.00 \pm 0.63$ & $95.20 \pm 0.92$ \\
\hline $3 \mathrm{ml} / \mathrm{kg} P J$ & $32.40 \pm 3.80^{*}$ & $0.60 \pm 0.05^{\alpha}$ & $128.40 \pm 0.93^{\alpha}$ & $3.52 \pm 0.07^{\alpha}$ & $23.20 \pm 0.92^{*}$ & $85.00 \pm 2.05^{*}$ \\
\hline $6 \mathrm{ml} / \mathrm{kg} P J$ & $35.80 \pm 1.07^{*}$ & $0.34 \pm 0.04^{*}$ & $128.60 \pm 0.06^{\alpha}$ & $3.52 \pm 0.13^{\alpha}$ & $20.40 \pm 0.75^{*}$ & $87.00 \pm 1.66^{*}$ \\
\hline $9 \mathrm{ml} / \mathrm{kg} P J$ & $35.60 \pm 0.93^{*}$ & $0.36 \pm 0.03^{*}$ & $129.30 \pm 0.58^{\alpha}$ & $3.18 \pm 0.11^{\alpha}$ & $29.20 \pm 0.49^{\alpha \#}$ & $85.40 \pm 1.40^{*}$ \\
\hline
\end{tabular}

Results are presented as Mean \pm SEM. Data are compared down the table

* Significantly different from control at $p<0.05$

${ }^{\alpha}$ Not significantly different from control at $\mathrm{p}<0.05$

\# Significantly different from group B at $\mathrm{p}<0.05$

Table 4: Effects of PJ on Markers of Liver Function

\begin{tabular}{|l|l|l|l|l|l|l|}
\hline $\begin{array}{l}\text { Experimental } \\
\text { Groups }\end{array}$ & $\begin{array}{l}\text { Total } \\
\text { protein } \\
(\mathrm{g} / \mathrm{dl})\end{array}$ & $\begin{array}{l}\text { Bilirubin } \\
(\mathrm{mg} / \mathrm{dl}-1)\end{array}$ & $\begin{array}{l}\text { ALP } \\
\text { I.U/L }\end{array}$ & $\begin{array}{l}\text { ALT } \\
\text { I.U/L }\end{array}$ & $\begin{array}{l}\text { ALB } \\
\text { I.U/L }\end{array}$ & $\begin{array}{l}\text { AST } \\
\text { I.U/L }\end{array}$ \\
\hline Control & $4.92 \pm 0.10$ & $0.22 \pm 0.05$ & $40.0 \pm 4.05$ & $86.0 \pm 2.68$ & $3.16 \pm 0.09$ & $115.2 \pm 1.46$ \\
\hline $3 \mathrm{ml} / \mathrm{kg} P J$ & $7.28 \pm 0.39^{*}$ & $0.16 \pm 0.02$ & $88.0 \pm 4.10^{*}$ & $59.8 \pm 3.90^{*}$ & $4.18 \pm 0.20^{*}$ & $154.6 \pm 7.07^{*}$ \\
\hline $6 \mathrm{ml} / \mathrm{kg} P J$ & $9.62 \pm 0.84^{*}$ & $0.28 \pm 0.02^{\alpha}$ & $118.4 \pm 3.43^{*}$ & $100.4 \pm 0.75^{*}$ & $6.04 \pm 0.33^{*}$ & $163.2 \pm 13.7^{*}$ \\
\hline $9 \mathrm{ml} / \mathrm{kg} P J$ & $5.76 \pm 0.30$ & $0.30 \pm 0.04^{\alpha}$ & $79.4 \pm 6.61^{*}$ & $72.2 \pm 3.90$ & $3.84 \pm 0.02$ & $178.4 \pm 2.00^{*}$ \\
\hline
\end{tabular}

Results are presented as Mean \pm SEM. Data are compared down the table

* Significantly different from control at $\mathrm{p}<0.05$.

${ }^{\alpha}$ Not significantly different from control at $\mathrm{p}<0.05$.

Table 5: Effects of PJ on some Gastric Enzymes of Wistar Rats

\begin{tabular}{|l|l|l|l|l|}
\hline $\begin{array}{l}\text { Experimental } \\
\text { Groups }\end{array}$ & $S O D(\mathrm{mg} / \mathrm{kg})$ & TBAR $(\mathrm{mg} / \mathrm{kg})$ & CATAL $(\mathrm{mg} / \mathrm{kg})$ & $M D A(\mathrm{mg} / \mathrm{kg})$ \\
\hline Control & $0.79 \pm 0.02$ & $0.001 \pm 0.00$ & $1.33 \pm 0.00$ & $0.02 \pm 0.00$ \\
\hline $3 \mathrm{ml} / \mathrm{kg} P J$ & $0.85 \pm 0.09$ & $0.001 \pm 0.002^{\alpha}$ & $1.34 \pm 0.00^{\alpha}$ & $0.016 \pm 0.002^{\alpha}$ \\
\hline $6 \mathrm{ml} / \mathrm{kg} P J$ & $0.69 \pm 0.004^{*}$ & $0.001 \pm 0.00^{\alpha}$ & $1.35 \pm 0.00^{\alpha}$ & $0.02 \pm 0.00^{\alpha}$ \\
\hline $9 \mathrm{ml} / \mathrm{kg} P J$ & $0.85 \pm 0.02$ & $0.0014 \pm 0.00^{\alpha}$ & $1.34 \pm 0.00^{\alpha}$ & $0.016 \pm 0.002^{\alpha}$ \\
\hline
\end{tabular}

Results are presented as Mean \pm SEM. Data are compared down the table

* Significantly different from control at $\mathrm{p}<0.05$.

${ }^{\alpha}$ Not significantly different from control at $\mathrm{p}<0.05$. 
Table 6: Effects of Pineapple Juice on Haematological Parameters in Wistar Rats

\begin{tabular}{|c|c|c|c|}
\hline $\begin{array}{l}\text { Experimental } \\
\text { Groups }\end{array}$ & $\mathrm{HB} \mathrm{g} / 100 \mathrm{ml}$ & $R B C \times 106 / \mathrm{mm} 3$ & $T W B C \times 103 / \mathrm{mm} 3$ \\
\hline Control & $11.85 \pm 2.0$ & $6.27 \pm 0.1$ & $2.35 \pm 0.6$ \\
\hline $3 \mathrm{ml} / \mathrm{kg} P J$ & $8.90 \pm 0.5 *$ & $4.34 \pm 0.2 *$ & $2.26 \pm 0.1^{\alpha}$ \\
\hline $6 \mathrm{ml} / \mathrm{kg} P J$ & $11.10 \pm 0.5^{\alpha \#}$ & $6.34 \pm 0.3^{\alpha}$ & $2.80 \pm 0.3^{\alpha}$ \\
\hline $9 \mathrm{ml} / \mathrm{kg} P J$ & $14.12 \pm 1.5$ *\# & $9.92 \pm 1.5 * \#$ & $4.47 \pm 0.5$ *\# \\
\hline
\end{tabular}

\section{DISCUSSION}

Pineapple juice in diet has been reported to naturally reduce the amount of cholesterol in bloodstream. [4-5,42]. Result from the present study revealed that administration of pineapple juice to the animals led to reduction in the mean organ weights (Table 1). Therefore, the reduction in the organ weights might be as a result of the cholesterol lowering property of pineapple juice.

Table 2 shows the effect of pineapple juice administration on lipid parameters in Wistar rats. There was a significant decrease in the cholesterol level in the treated groups B and D when compared with the control group. This is in support with the report from the research available in the December 2005 edition of "Medical Science Monitor", which studied the effect of pineapple and other fruit juices on plasma lipids. Researchers discovered that rats that consumed pineapple juice over a three-hour period experienced a decrease in lipoprotein particles, compounds that carry fat through the blood, and increased metabolism, activities that lower cholesterol levels. It is worth noting that there was a progressive significant increase in low density lipo-protein which later decreased in the highest dosed group. It can then be inferred that this effect of the juice on the liver, kidney and stomach is dose-dependent. As this was an animal study, human studies are required. However, all the treated groups show no significant difference when compared with the control group in terms of triglyceride concentration. Prasenjit et al., in 2012 have previously reported that fibers in pineapple caused lower blood cholesterol, which resulted into reduced risk of heart diseases, diabetes, constipation, metabolic syndrome, high blood pressure, excess abdominal weight and high triglyceride levels [2]. The result from this study is in tandem with their report, confirming the triglyceride reduction property of pineapple juice.

It was observed that group $C$ showed a significant increase in high density lipo-protein concentration when compared with that of the control group while group D showed a significant decrease.

The results showed that there is significant decrease in the concentration of urea and creatinine in all the treated groups when compared with the control (Table 3). This implies that pineapple juice has very low or no toxicity but rather reduces it. This supports the report made by [43] that bromelain (the major proteolytic enzyme derived from pineapple) is considered to have very low toxicity, with an $\mathrm{LD}_{50}$ greater than $10 \mathrm{~g} / \mathrm{kg}$. Toxicity tests on dogs, with increasing levels of bromelain up to $750 \mathrm{mg} / \mathrm{kg}$ administered daily, showed no toxic effects after six months. Dosages of $1.5 \mathrm{~g} / \mathrm{kg} /$ day administered to rats showed no carcinogenic or teratogenic effects. Sodium and potassium values for all the treated groups on the other hand, showed no significant difference when compared with the control group. This shows that pineapple juice administration does not cause any increase in the level of sodium and potassium beyond what the normal body needs. It has been shown that the fruit contains sugar, vitamin $\mathrm{C}$, and bromelain, a proteolytic enzyme that breaks down protein. It is also low in sodium and rich in potassium [4-5]. This agrees with the decision made by the Institute of Medicine, National Academies of Science in 2005 that "The Dietary Reference Intakes for Sodium is established to be Tolerable Upper Intake Level (UL), which is the highest daily nutrient intake level that is likely to pose no risk of adverse health effects". The result from the table showed that bicarbonate and chloride values reduced significantly down the groups 
when compared with the control group. However, Pellicano et al., (2009) reported that in a pilot study, bromelain, in combination with sodium alginate, sodium bicarbonate, and essential oils, significantly improved dyspeptic symptoms [44]

From the results, the level of alkaline phosphatase, aspartate aminotransferase and alanine amino transferase showed significant increase in the experimental rat when compared with the control (Table 4). This could be attributed to the dose administered. Therefore, one can deduce that lower dose of the juice had no significant positive action in reducing these enzymes and at the same time, excess dose potentiates the recruitment of these enzymes (Table 4). However, elevation in ALP, AST and ALT are usually secondary to tissue damage. This is because such damage results in the leakage of these enzymes from their intracellular stores into plasma. ALT is most prevalent in the liver whereas AST may also be found in the heart, skeletal muscle and liver to nearly the same extent [45]. Significant increases in the transaminases commonly accompany such liver diseases as toxic hepatitis, acute liver necrosis and hepatic cirrhosis.

The present study showed significant changes in the results of Total Protein of the experimental rats when compared with the control. This is an indication that moderate administration of pineapple juice had positive effect on the Total Protein, by increasing its concentration when compared with the control group.

It was also observed from result that there was no significant difference $(p>0.05)$ in the level of bilirubin of the experimental animals when compared with the control. Reports from previous works have shown that alcohol consumption may inhibit protein synthesis, especially in the heavy drinkers. The binding and transport of substances by albumin, such as bilirubin could be affected by heavy or moderate alcohol consumption. Bilirubin is transported to the liver by binding noncovalently to albumin [46].

SOD showed a significant decrease $(\mathrm{p}<0.05)$ in group $\mathrm{C}$ when compared with control. However, TBAR, CATAL and MDA showed no significant difference when compared with the control (Table 5).

Table 6 shows the effects of pineapple juice on Haemoglobin (HB), Red Blood Cells (RBC) and Total White Blood Cells (TWBC) indices of the Wistar Rats. The results showed that there were significant increase $(p<0.05)$ in the total values of $\mathrm{Hb}, \mathrm{Rbc}$ and TWBC contents of the experimental rats when compared with the control. Moderate administration of pineapple juice proved to be advantageous in that it increases the Haemoglobin contents $(\mathrm{Hb})$, the erythropoesis formation and serves as immune buster as shown by this result. There was a significant decrease in haemoglobin concentration observed in group B when compared with the control. This is in contrast with the result which was reported by Boukerche et al., (2004) [47].

\section{CONCLUSIONS}

We conclude that when pineapple juice is moderately administered orally for the period of one month in wistar rats, it had some gastric protective effects in that it reduced some toxic gastric enzymes and cholesterol level. It also has positive haematological and biochemical significances because it potentiated increased erythropoetic activities. However, this is not so in the case of its effect on the levels of ALP, AST and ALT in the study. Further study will therefore be required to find which dose is the best for the optimum physiochemical function of the juice in this area.

\section{REFERENCES}

[1] Information on: Dictionary.reference.com, Retrieved on 2009-12-06.

[2] Prasenjit Debnath, Prasanta Dey, Abhijit Chanda, Tejendra Bhakta, A Survey on Pineapple and its medicinal value, Scholars Academic Journal of Pharmacy. 1(1) (2012).

[3] Nutritiondata.com, 2011. Nutritional Facts and Analysis for pineapple, raw, extra sweet variety.

[4] Bartholomew DP, Paull RE and Rohrbach KG; The Pineapple: Botany, Production and Uses, CABI Publishing, Wallingford UK, 2003: 21. 
[5] A. Davidson, The Penguin Companion to Food, Penguin Books, 2008.

[6] GC Tassman, JN Zafran, GM Zayon, A double-blind crossover study of a plant proteolytic enzyme in oral surgery, The Journal of Dental Medicine. 20 (1965) 51-54.

[7] GC Tassman, JN Zafran, GM Zayon, Evaluation of a plate proteolytic enzyme for the control of inflammation and pain, Journal of Dental Medicine. 19 (1964) 73-77.

[8] RCL Howat, GD Lewis, The effect of bromelain therapy on episiotomy wounds - a double blind cont rolled clinical trial, Journal of Obstetric $\mathrm{s}$ and Gynaecology of the British Commonwealth. 79(10) (1972) 951-953.

[9] S. Brien et al., Bromelain as a treatment for osteoarthritis: are view of clinical studies, Evidence-Based Complementary and Alternative Medicine. 1(3) (2004) 251-257.

[10] Rajendra Pavan, Sapna Jain, Shraddha, Ajay Kumar, Properties and Therapeutic Application of Bromelain: A Review, Biotechnology Research International. (2012), Article ID 976203.

[11] S. J. Taussig, S. Batkin, Bromelain, the enzyme complex of pineapple (An anas comosus) and its clinical application: an update, Journal of Ethnopharmacology. 22(2) (1988) 191-203.

[12] S. Mondal, S. Bhattacharya, J. N. Pandey, M. Biswas, Evaluation of a cute anti-inflammatory effect of Ananas Comosus leaf extract in Rats, Pharmocology online. 3 (2011) 1312- 1315.

[13] R.M. Heinicke, W.A. Gortner, Stem bromelain: a new pro tease preparation from pineapple plants, Economic Botany. 11(3) (1957) 225-234.

[14] M Livio, G De Gaetano, MB Donati, Effect of bromelain on fibrinogen level, prothrombin complex factors and platelet aggregation in rat: a preliminary report, Drugs under Experimental and Clinical Research. 4 (1978) 21-23.

[15] R.A. Neubauer, A plant protease for potentiation of and possible replacement of antibiotics, Experimental Medicine and Surgery. 19 (1961) 143-160.

[16] H. Barth, A. Guseo, R. Klein, In vitro study on the immunological effect of bromelain and trypsin on mononuclear cells from humans, European Journal of Medical Research. 10(8) (2005) 325-331.

[17] L.P. Hale, B.F. Haynes, Bromelain treatment of human T cells removes CD44, CD45RA, E2/MIC2, CD6, CD7, CD8, and Leu 8/LAM1 surface molecules and markedly enhances CD2mediated T cell activation, Journal of Immunology. 149(12) (1992) 3809-3816.

[18] P.V. Lehmann, Immunomodulation by proteolytic enzymes, Nephrology Dialysis Transplantation. 11(6) (1996) 953-955.

[19] L. Desser, A. Rehberger, W. Paukovits, Proteolytic enzymes and amylase induce cytokine production in human peripheral blood mononuclear cells invitro, Cancer Biotherapy. 9(3) (1994) 253-263.

[20] L. Desser, A. Rehberger, E. Kokron, W. Paukovits, Cytokine synthesis i n human peripheral blood mononuclear cells after oral administration of polyenzyme preparations, Oncology. 50(6) (1993) 403-407.

[21] K. Eckert et al., Effects of oral brome-lain administration on the impaired immunocy totoxicity of mononuclear cells from mammary tumor patients, Oncology Reports. 6(6) (1999) 1191-1199.

[22] C. R. Engwerda, D. Andrew, A. Ladhams, T. L. Mynott, Bromelain modulates T cell and B cell immune responses in vitro and invivo, Cellular Immunology. 210(1) (2001) 66-75.

[23] C. R. Engwerda, D. Andrew, M. Murphy, T. L. Mynott, Bromelain activates murine macrophages and natural killer cells invitro, Cellular Immunology. 210(1) (2001) 5-10.

[24] J. L. Slavin, B. Lloyd, Health benefits of fruits and vegetables, Advances in Nutrition: An International Review Journal. 3(4) (2012) 506-516.

[25] Xi Yang, William F Salminen, Laura K Schnackenberg, Current and emerging biomarkers of hepatotoxicity, Division of Systems Biology, National Center for Toxicological Research, US Food and Drug Administration, Jefferson, AR, USA Current Biomarker Findings 2012:2 43-55 (http://dx.doi.org/10.2147/CBF.S27901)

[26] J Ozer, M Ratner, M Shaw, W Bailey, S. Schomaker, The current state of serum biomarkers of hepatotoxicity, Toxicology. 245(3) (2008) 194-205. 
[27] E.G. Giannini, R. Testa, V. Savarino, Liver enzyme alteration: a guide for clinicians, Canadian medical association journal. 172(3) (2005) 367-379.

[28] I. Osuala Fidelia, A.A. Otitoloju, M.N. Igwo-Ezikpe, Usefulness of liver and kidney function parameters as biomarkers of 'heavy metals' exposure in a mammalian model Mus musculus, African Journal of Biochemistry Research. 8(3) (2014) 65-73.

[29] OA Oyesola, TO Oyesola, AI Izagbo, 2013 Pineapple Juice Administration and Gastric Ulcer in Wistar Rats, J. Med. Sci. 13 (6) (2013) 446-452.

[30] OH Lowry, NJ Rosenbrough, AL Farr, RJ Randall, Protein measurement with the Folin Phenol Reagent, J. Biol. Chem. 193 (1957) 265-275.

[31] L Goth, A simple method for determination of serum catalase activity and revision of reference range, PubMed- indexed for MEDLINE, 196(2-3) (1991) 143-151.

[32] HP Misra, I. Fridovich, The role of superoxide anion in the antioxidation of epinephrine and a simple assay for superoxide dismutase. J. Bio chem. 247 (10) (1972) 3170-3175.

[33] J.A.Buege, S.D. Aust, Microsomal Lipid Peroxidation Methods in Ezymology, Science and Education Publishing. 52 (1978) 302-310.

[34] S.M. Abubakar, M.S. Sule, Effect of Oral Administration of Aqueous Extract of Cassia Occidentalis L. Seeds On Serum Electrolytes Concentration in Rats, Bayero Journal of Pure and Applied Sciences. 3(1) (2010) 183-187.

[35] M. Magoshes, B.L. Vallee, Flame Photometry and Spectrometry, New York J. Intern. Sci. 2(1) (1956) $13-16$.

[36] O. Schales, S.S. Schales, A Simple and Accurate Method for Determination of Chloride in Biological Fluids, J. Biol. Chem. 140(5) (1941) 879-882.

[37] D.D. Van Slyke, F.M. Neil, The determination of gases in blood and other solutions by vacuum extraction and manometric measurement, J. Biol. Chem. 61(2) (1924) 523-573.

[38] B.T.Doumas, W.A. Watson, H.G. Biggs, Albumin Standards and the measurement of serum albumin with brancresol green, Chin chim Acta. 258(1) (1971) 87-96.

[39] L. Jendrassik, P. Grof, Vereinfachte photometrische methoden zur bestimmung des blutbilirubins, Biochem Z. 297(8) (1938) 1-9.

[40] S. Reitman, S. Frankel, Glutamic - pyruvate transaminase assay by colorimetric method, Am. J. Clin. Path. 28 (1957) 56.

[41] L.A. Babson, Estimation of Alkaline phosphatase activity. Clinical Chimica Acta. 31 (1965) 87-96.

[42] Oxford English Dictionary entries for pineapple and pine cones, 1971.

[43] S.J. Taussig et al., Bromelain: a proteolytic enzyme and its clinical application, Hiroshima J. Med. Sci. 24 (1975) 185-193.

[44] R. Pellicano, S. Strona, D. Simondi, Benefit of dietary integrators for treating functional dyspepsia: a prospective pilot study, Minerva Gastroenterol Dietol. 55 (2009) 227-235.

[45] ER Orhue, AU Osaigbovo, DE Vwioko, Growth of maiz (Zea mays L.) and changes in some chemical properties of an ultisol amended with brewery effluent, Afr. J. Biotechnol. 4 (2005) 973978.

[46] GM Wardlaw, M Kessel, Perspective in Nutrition (5th ed), McGraw Hill, Boston, 2002.

[47] S Boukerche, W Aouacheri, S Saka, Les effets toxiques des nitrates: étude biologique chez l'homme et chez l'animal, Ann. Biol. Clin. 65(4) (2004) 385-391. 